\title{
The Criticizing Strategies by the National Campaign Team (TKN) and the National Winning Agency (BPN) in the 2019 Presidential Election Debate
}

\author{
Nurul Rahmadani ${ }^{1} \&$ Agustina $^{2}$

\begin{abstract}
${ }^{1}$ Faculty of Languages and Arts, Universitas Negeri Padang, Padang, West Sumatra 25131, Indonesia
${ }^{2}$ Faculty of Languages and Arts, Universitas Negeri Padang, Padang, West Sumatra 25131, Indonesia

*Corresponding author. Email: agustina@fbs.unp.ac.id
\end{abstract}

\begin{abstract}
This research was motivated by the dominant use of criticism by TKN and BPN in the 2019 Presidential Election Debate. Therefore, this research aims to: (1) uncover the types of criticizing strategies used by TKN and BPN, and (2) to explain and describe the use of criticizing strategies in the 2019 Presidential Election Debate. The source of this research data was the verbal utterances sourced from the 2019 Presidential Election Debate video. The data was collected by downloading the debate video on YouTube, then it was transcribed. Based on the listening and the note technique, TKN and BPN's utterances which were criticized were identified, then it was classified and analyzed based on the research objectives. Based on the results of the data analysis, it was found that the TKN and BPN used three types of criticizing strategies, namely direct, indirect, and mixed criticism. From the 182 data found, there were 107 data which were direct criticism, 64 data which were indirect criticism, and 11 data which were mixed criticism. The use of direct strategy is more dominant, in three main forms, which were negative evaluation, statement of the problem, and rejection. Therefore, the criticizing strategy used by TKN and BPN in the 2019 Presidential Election Debate is more explicit in the forthright form, so that it looks more accentuating the lack of opponents, even dropping the opponents; on the other hand, it further reveals the greatness of the party itself, so that it is impressed to take political advantage.
\end{abstract}

Keywords: Criticizing Strategies, TKN, BPN, Presidential Election Debate.

\section{INTRODUCTION}

In its function as a communication tool, language has a very close relationship with its role in building the culture and civilization of a nation. Therefore, through the use of good and correct language, the user's identity will be reflected as well as the characters that make up his personality.

The use of good and correct language in communication becomes important to note in every utterance. This is because the use of good and correct language will grow the polite language. The use of polite language is not only needed in general speaking, but it is also used in politics, especially in criticizing. Although in politics, generally the function of language is more likely to be competitive, but the use of polite language is still needed because it will affect the social relations of speakers with the social communities in the communication process. This is because politeness is related to respect, courtesy, good attitude towards appropriate behavior. Based on Grice (in Rusminto 2012, p.106), politeness in speaking aims to regulate the rights and obligations of the speaker with the interlocutor, so that there will be good cooperation between the two. Wibowo (2013) said that while communicating, there is also an obligation to keep harmonious relations between the speaker and the interlocutor which is called politeness.

The researches on the politeness of language which are related to criticizing utterances have been done a lot, including in USA by (Pérez De Ayala, 2001), (Nuolijärvi \& Tiittula, 2011), (Walker et al., 2012), and (GrebelskyLichtman, 2016); in England by (Bargiela-chiappini, 2003), (Culpeper et al., 2003), (Jansen \& Janssen, 2010), (Rudanko, 2006); in France by (Ladegaard, 2004), and (Fracchiolla, 2011); and in Indonesia by (Yusri, 2015) ; Hamdani (2015), (Panca, 2016), (Hefdzil, 2017), (Agustina \& Syahrul R, 2017), (Firdaus, 2019), (Priyanto, 2018), (Pangestika, 2018), and (Mustika et al., 2019). Based on some results of the researches, it can be concluded that language in political matters or as a political tool can be of no value because it becomes a means to attack, bring down, swear, even to the scolding, and spit out ugliness of political opponents.

One agenda that is prevalent in politics is debate. Debating means talking to the other person to defend or attack his/her opinion, collide intelligence and logic in discussing a problem Widyamartaya $(1991$, p.21) b. In the elections context, each debate event is inseparable from the activities of criticizing and being criticized by both parties 
who are debating. Based on Brown and Levinson (in Jauhari, 2018), criticism is a speech act that is prone to threatening the face, because criticism can be followed by an expression of giving a negative evaluation or a bad evaluation to the target of criticism. On the other hand Thi \& Hoa $(2007, \mathrm{p}, 136)$ said that criticizing is sometimes performed to vent the speakers negative feeling or attitude to the hearer or the hearer's work, choice, behavior, etc. because based on Shang-chao (2008, p.67) criticism relate to negative evaluations to an individual. If understood more closely, the definition of criticism raised by the experts above shows the similarity that criticism is related to negative or bad judgments about one's behavior or actions. Because of that, the language of criticism is highlighted negatively because there are factors that use political interests and profits.

Further, according to Nguyen (2008, p.43) criticizing is an illocutionary act that aims to provide a negative evaluation of the actions, choices, words, and products that are the responsibility of the speaker. This action is done in the hope to influence the speech partners in the future to make them better. That is, criticizing in this context means giving comments, whether in the form of opinions, suggestions, input or refutation to someone. Furthermore, Nguyen (2008) defined that there are two criticizing strategies, which are direct and indirect criticizing strategies. The direct criticizing strategy includes the following sub-types: (a) negative evaluation, (b) rejection, (c) expression of disapproval, (d) statement of problem, (e) statement of difficulty, (f) consequences. Whereas, the types of indirect criticizing strategy are divided into: (a) improvement, (b) indicating the standard, (c) an order for changes, (d) request for changes, (e) advice about changes, (f) suggestions for changes, (g) expressions of uncertainty, (h) asking/thinking, (i) other signals. Both types of strategies are the theoretical foundation in this study.

\section{METHOD}

In general, this type of research was descriptive qualitative, but a simple quantitative type was also used Afrizal (2015, p.11) to reveal the percentage comparison between the types of criticizing strategies used. The data of this research was the utterances of TKN and BPN in the Presidential Election Debate event in the "Mata Najwa" program which aired during the 2019 Presidential Election Campaign. The data was collected by downloading the debate video on youtube, then it was transcribed. Based on the listening and the note technique, TKN and BPN's utterances which were criticized were identified, then it was classified and analyzed based on the research objectives. So, this research used a theoretical and methodological approach. The theoretical approach was focused on the Pragmatic aspect with the aim to uncover the relationship of language with the context built in the oral communication, while the methodological approach aims to analyze descriptively the criticizing strategies used by TKN and BPN in the 2019 Presidential Election Debate.

\section{RESULTS AND DISCUSSION}

Based on the results of data analysis, it was found two types of criticizing strategies used by TKN and BPN in the 2019 Presidential Election Debate, namely direct strategy and indirect strategy. The use of these strategies in detail can be seen in Table 1 .

Table 1 The Use of Criticizing Strategies by TKN and BPN in the 2019 Presidential Election Debate

\begin{tabular}{|c|c|c|c|c|}
\hline No. & $\begin{array}{l}\text { The Types of } \\
\text { Criticizing Strategies }\end{array}$ & Sub-Types & $\begin{array}{l}\text { The Number } \\
\text { of Utterances }\end{array}$ & Percentage \\
\hline \multirow[t]{7}{*}{1.} & \multirow{7}{*}{$\begin{array}{l}\text { Direct Criticizing } \\
\text { Strategy }\end{array}$} & 1. Negative Evaluation & 32 & $30, \%$ \\
\hline & & 2. Rejection & 27 & $25 \%$ \\
\hline & & 3. Expression of disapproval & 5 & $5 \%$ \\
\hline & & 4. Statement of problem & 31 & $29 \%$ \\
\hline & & 5. Statement of difficulty & 5 & $5 \%$ \\
\hline & & 6. Consequences & 7 & $6 \%$ \\
\hline & & Total & 107 & $63 \%$ \\
\hline \multirow[t]{10}{*}{2.} & \multirow{9}{*}{$\begin{array}{l}\text { Indirect Criticizing } \\
\text { Strategy }\end{array}$} & 1. Improvement & 12 & $19 \%$ \\
\hline & & 2. Indicating the standard & 2 & $3 \%$ \\
\hline & & 3. An order for changes & 9 & $14 \%$ \\
\hline & & 4. Request for changes & 8 & $13 \%$ \\
\hline & & Advice about changes & 14 & $22 \%$ \\
\hline & & Suggestions for changes & 2 & $3 \%$ \\
\hline & & Expressions of uncertainty & 2 & $3 \%$ \\
\hline & & Asking /thinking & 15 & $23 \%$ \\
\hline & & Total & 64 & $(37 \%)$ \\
\hline & & Total & 171 & $100 \%$ \\
\hline
\end{tabular}




\section{The use of Direct Criticizing Strategy}

Direct Strategy is a criticizing strategy that contains criticism that explicitly shows the problem of action and performance (Nguyen, 2008). In the 2019 Presidential Election Debate, it was found six types of criticizing strategies used by TKN and BPN, which were (1) negative evaluation, (2) statement of problem, (3) rejection, (4) consequences, (5) expression of disapproval, (6) statement of difficulty.

From the six strategies used, the types 1-3 were used very dominantly, namely negative evaluation (data 1), statement of problem (data 2), and rejection (data 3 ).

(1) "Saya kira rakyat perlu diingatkan kembali tentang apa itu ABS atau Asal Bapak Senang. Ini sebuah kata yang popular pada masa orde baru ketika mantan mertuanya Pak Prabowo berkuasa dan Pak Prabowo merupakan bagian integral dari kekuasaan pada masa itu." (MN-SKL-ABS-TKN01-01).

'I think the people need to be reminded of what is ABS or the origin of the father pleased. This is a popular word during the new order when his former father-in-law Pak Prabowo came to power and Pak Prabowo was an integral part of the power of the time'.

(2) 'Bagi saya bukan kesombongaan. Tapi ini mereka sudah playingglot, playing institution bahkan itu menurut saya bahaya. Ini bisa jatuh kepada individualisasi politik, ini bisa jatuh kepada keuntungan individu. Kita tidak bisa kalau suatu saat Pak Prabowo menjadi presiden ia akan mengatakan saya lebih Indonesia dari pada 260 juta rakyat Indonesia'. (MN- SKL-PIL-TKN-1802)

'To me is not an arrocomor. But these are already playingglot, playing institution even it's in my opinion danger. This could fall into political individualization, this could fall into individual gains. We cannot if Mr. Prabowo became president he would say I was more Indonesian than 260 million Indonesians'.

(3) Harus dibedakan ya antara marah-marah, tegas, dan suara keras. Itu harus dibedakan." (MNSKL-PIL-BPN-10-02).

'Must be differentiated yes between angry, assertive, and loud voice. It must be distinguished'.

Criticism in the data (1) was found in the Presidential Election Debate on the topic of ABS (Asal Bapak Senang). The data was a negative evaluation type of the direct criticizing strategy. The criticism aimed to criticize Prabowo's actions during his former in-law's tenure, it was to provide information to Indonesian society then to remind that do not forget the situation of the power of the new order, and Prabowo was an integral part of the power at that time. The criticism gave a negative assessment to
Prabowo with a statement "Saya kira rakyat perlu diingatkan kembali tentang apa itu $A B S$...." In words "diingatkan kembali", it could be concluded that the criticism contains the meaning of negative evaluation that is conveyed directly. The criticism in the data (2) which was submitted by TKN was a strategy to criticize the problem statement because the criticism mentioned errors and problems which were found in BPN actions. In the data, TKN criticized Prabowo's words when expressing the sentence "Saya lebih TNI dari pada banyak TNI" in the previous speech, which was according to TKN, it would be a concern if Prabowo became president he would say I am more Indonesian than 260 million Indonesians. Then, the rejection type of direct criticizing strategy in the data (3) was marked by a description of the attitude of the speaker (P) to the speaker partner's action (MT). In this case, BPN criticism was addressed to TKN who reject the previous criticism of Prabowo as being angry, arrogant, and so on. In the criticism, BPN asked TKN to distinguish which were angry, assertive, and loud voice, which was marked by a statement "harus dibedakan ya" which contained the rejection of the previous statement.

Although it was not dominant, there were also found the expressions of disapproval (data 4), statements of difficulty (data 5), and consequences (data 6) types of direct criticizing strategies, as follows:

(4) "Saya jawab. Amin Rais 2019 bukan Amin Rais 1998 ya. Amin Rais 2019 adalah Amin Rais yang ingin surfive dalam politik satu." (MN- SKLKAPPAR-TKN-41-04).

'I replied. Amin rais 2019 not Amin Rais 1998 Yes. Amin Rais 2019 is Amin Rais who wants to surfive in politics one'.

(5) "Apanya ya yang tidak efektif, saya tidak mengerti yang tidak efektif?" (MN- SKL-DADDPK -TKN-74-03).

'What is ineffective, I do not understand the ineffective?'

(6) "Ini adalah keamanan domestik. Kalau tidak kita kunci keamanan kita ini, kita akan kehilangan apa? Ya, 220 juta orang yang hilang termasuk kita dan sumber daya alam kita. Jadi tolong dilihat ya apa yang disampaikan Pak Prabowo." (MN- SKL-PIL-BPN-11-02).

'This is domestic security. Otherwise we key this to our security, we will lose what? Yes, 220 million people are missing including us and our natural resources. So please see ya what is delivered by Mr. Prabowo'.

The data (4) was the strategy of direct criticism in the form of expressions of disapproval, because the utterance was delivered with conflicting arguments which was marked by negation bukan. In the statemen, TKN did not agree that Amin Rais now was different with the old one by saying “Amin Rais 2019 bukan Amin Rais 1998." ... who want to serfive in politics one. In the data (5), it was used direct criticizing strategy in the form statements of 
difficulty, which was delivered with the statement that was difficult to understand, it was "Apanya ya yang tidak efektif, saya tidak mengerti yang tidak efektif?" The meaning of the utterance revealed by TKN was it the lack of understanding of what the BPN team has conveyed to the cards contained in the Jokowi program, which was deemed ineffective. In the statement, the statements of difficulty in criticizing strategy was marked in the words "saya tidak mengerti". Next, the used of consequence criticizing strategy in the data (6) was a criticism that was intended as a warning against to the negative consequences of the actions of the speaker partner, which was indicated by a statement "Kalau tidak kita kunci domestik kita ini yang kehilangan 220 juta orang, termasuk sumber daya alam.." It means, the emphasis is on the maintaining security, human resources and natural resources by giving warnings.

\section{The use of Indirect Criticizing Strategy}

The use of indirect criticizing strategy by TKN and BPN in the 2019 Presidential Election Debate was found in the six types, however, only three were dominant, which were in form asking / thinking (data 7), advice about changes (data 8), and improvement (data 9).

(7) "Lakukan apa yang kau katakan yah. Satu kata dalam perbuatan. Pak Jokowi gak perlu ngomong itu ya. Data mengatakan bukan dusta karena Pak Jokowi berdasarkan pada data yang lain berpihak pada dusta." (MN-SKTL-DSDTKN-05-03).

'Do what you say well. One word in action. Pak Jokowi doesn't need to say that. The data says it's not a lie because Pak Jokowi is besed on other data in favor of the lie'.

(8) "Jangan kita jadi korban teknologi untuk kepentingan asing. Itu yang ada dikepala orang yang berpikir jangka panjang. Bukan tergoda dengan teknologi pemasar teknologi yang datang begitu saja ke negara ini." (MN-SKTL-DSD-0303)

'We should not be victims of technology for foreign interest. That's exists in the heads of people who think long term. It's not tempting about technology marketer technology that comes to this country'.

(9) "Pancasila sudah selesai. Tujuan Pancasila memajukan kesejahteraan umum mencerdaskan kehidupan bangsa. Pak Jokowi ya sudah menekankan sekarang pada kesejahteraan umum dengan mendistribusikan dan peningkatan masyarakat dan desa. Kartu Indonesia pintar, untuk perencanaan kuliah nanti. Kartu prakerja itu adalah keberpihakan pada negoisasi-negoisasi sumber daya alam" (MN-SKTL-DSD-04-03).

'Pancasila is over. The purpose of Pancasila furthering the general welfare of the nation's life. Mr Jokowi has emphasized now on general welfare by distributing and improving the community and village. Indonesia smart card, for college planning later. The pre-practice card is a alignments to the negoisasi of natural resources'.

Criticism in the data (7) was asking type of indirect criticizing strategy which was delivered by TKN to BPN with an aim to aware that his actions were not in accordance with the reality, which was "Lakukan apa yang kau katakan yah. Satu kata dalam perbuatan. Pak Jokowi gak perlu ngomong itu ya." TKN explained that their team spoke in accordance with the data, meanwhile, the BPN team did not side with the data, but lied. Then, the data (8) was a criticism of advice about change, which was expressed in expressions of prohibition or reminder "Jangan kita jadi korban teknologi untuk kepentingan asing itu yang ada dikepala orang yang berpikir jangka panjang." This criticism was conveyed by BPN to TKN to advice by prohibiting the avoidance of victims of technology for foreign interests. Next, criticism in the data (7) in the form improvement to fix errors by including alternative actions, with a statement "Pak Jokowi ya sudah menekankan sekarang pada kesejahteraan umum dengan mendistribusikan" .... It means, Jokowi has improved performance compared to the previous president, such as village distribution and upgrading, smart Indonesia cards, Indonesian college planning cards, pre-employment cards and alignments on natural resource negotiations.

Beside it, other types of indirect criticizing strategy were also used in the 2019 Presidential Election Debate discourse, although they were not dominant, which were an order for changes (data 10), request for changes (data 11), indicating the standard (data 12), suggestions for changes (13), and expressions of uncertainty (data 14).

(10) "Keadilan itu harus ditegakkan Bung ..... harus ditegakkan!!” (MN-SKTL-HDP-33-01)

'Justice shall be established man..... Must be enforced!!'

(11) "Point pentingnya konsfirasi. Kita menginginkan pemilu yang releabel, orang benar-benar yakin siapa yang terpilih ya. Kita ingin dalam hal ini, kami ingin memohon-mohon sekali kepala KPU untuk selalu menunjukkan bahwa kedepannya $K P U$ netral dan sekarang sedang berjalan dan mudah-mudahan itu lebih penting." (MN-SKTLDSD-10-03).

'Importance points of Consfiracy. We want a election that is releabel, people are really sure who is elected yes. We want to in this case, we want to beg the head of the KPU to always show that the future is KPU neutral and is now running and hopefully it is more important'.

(12) "Kalau mau maju lagi sebenarnya kita tidak perlu KTP lagi. Nanti yang perlu kita lakukan dengan hanpond kita masing-masing dan itulah sebenarnya pemimpin itu dibangun bukan sekedar ilusi keinginan-keinginan yang tidak realistis tapi harus membumi dan berprestasi." (MN-SKTLDPK-45-03).

'If you want to move forward again we don't actually need a KTP anymore. Later what we need 
to do with each of our mobile phones and that is actually the leader is built not just the illusion of unrealistic desires but must grounded and achievers'

(13) "Kalau mau melakukan perbandingan itu harus cerdas secara matematik. Perbandingan 4 tahun itu harus dilakukan." (MN-SKTL-AAAVSM-5104)

'If you want to move forward again we don't actually need a KTP anymore. Later what we need to do with each of our mobile phones and that is actually the leader is built not just the illusion of unrealistic desires but must grounded and achievers'.

(14) "Begini Bang Prio. Semua orang bisa membicarakan tentang kemanusiaan dan keadilan, kesejahteraan, dan sebagainya. Persoalannya adalah bagaimana keputusan TKP mengenai penculikan. Bagaimana keputusan presiden Habibie tentang pemecatan, itu yang pertama. Apa mungkin mereka terlibat penculikan bisa bicara tentang kemanuasiaan. Sementara, mereka menghilanglan nyawa manusia. Artinya, menurut saya kalau seseorang yang sudah menurut TKP melakukan penculikan berbicara tentang kemanusiaan pasti omong kosong. Kedua, ada bagian di sana yang sekarang memimpin partai, yang dulu terbukti secara inkrah menembak seorang hakim, dan dipenjara 15 tahun, masuk nusakambangan dan sekarang keluar berbicara mengenai kemanusiaan, itu juga omong kosong. Nah, fakta-fakta ini juga harus kita buka agar rakyat tau, agar rakyat tau sedang berhadapan dengan siapa. Satunya penculik terbukti lewat KTP. terbukti lewat kebutuhan presiden yang satunya lagi terbukti kebutuhan pengadilan. Kalau kedua orang ini berkombinasi memimpin Negara, ini saya tidak mau!!!” (MN-SKTL-DOR-53-05).

"Here's Bang prio. Everyone can talk about humanity and justice, welfare, and so on. The issue is how the crime scene decisions about kidnapping. How did president Habibie's decision about the dismissal, it was the first. What they may be involved kidnapping can talk about the hypoaciation. Meanwhile, they eliminate human life. That is, I think that someone who is according to crime scene doing the kidnapping talks about humanity is definitely nonsense. Secondly, there is a section there that is now leading the party, which once proved to Inkrah shoot a judge, and imprisoned 15 years, enter Nusakambangan and now out talk about humanity, it is also nonsense. Well, these facts must also be open so that the people know, that the people know are dealing with WHO. Only the kidnapper is proven by KTP. Proved through the needs of the other president proved a trial needs. If both of these people have combinations leading the country, I do not want to!!!'.
Criticism in the data (10) was the form of an order for changes which was expressed by BPN to TKN with the statement "Keadilan itu harus ditegakkan Bung...", with the aim that justice be upheld by the government. In the data (11), the use of request for changes in criticizing strategy was marked by a statement of desire from the $\mathrm{BPN}$ team to TKN "kita menginginkan pemilu yang releabel" as a sign of a desire for changes to make elections run this way. Then, in the data (12), criticism in the form of suggestions for changes from TKN to BPN, which gave the suggestion "kalau mau maju sebenarnya kita tidak membutuhkan KTP, tetapi bisa dengan handphone masing-masing. "In the other hand, the data (13) showed the standard expressed with utterances which stated the collective obligation or as a rule that was considered by the speaker as something that was usually agreed upon and applied by everyone. This can be proven from the criticism statement that reads "Kalau mau melakukan perbandingan itu harus cerdas secara matematik. Perbandingan 4 tahun itu harus dilakukan." Based on the statement of criticism submitted by the BPN team to TKN, it was intended not to be arbitrary in comparing the performance of one camp to the other, it should be collective or as a rule that is considered a speaker as something that is usually agreed upon and applied by everyone. The data (14) expressed an expression of uncertainty about his actions that is not in accordance with the fact that "Prabowo pernah terlibat dalam peristiwa kemanusiaan yang berakibat pada penghilangkan nyawa manusia, dan pernah menembak seorang hakim, dipenjara 15 tahun masuk nusakambangan keluar berbicara mengenai kemanusiaan omong kosong untuk mencalon sebagai calon presiden." This statement aims to open the minds of the Indonesian people to think many times in choosing a president. Based on this, the words "Apa mungkin" showed the uncertainty in the expression of uncertainty types of criticizing strategy.

Based on the results of data analysis, it can be concluded that the type of criticizing strategy used by TKN and BPN in the 2019 Presidential Election Debate is dominated by the direct strategy of $63 \%$, while the use of indirect criticizing strategy is only $37 \%$. It means, the use of criticism frankly is preferred by the TKN and BPN in the Presidential Election Debate than the use of more polite criticism. If the results of Nguyen (2008) research directly criticize contain criticism that explicitly points out problems regarding action and performance, then in the Presidential Election Debate discourse direct criticism is aimed more at actions that tend to characterize the intended party. This can be seen from the data found generally tends to criticize actions in the form of behavior and personality, with the choice of a type of negative evaluation strategy, a statement of the problem, and a potentially subjective rejection. This is in line with the results of previous studies, including by Agustina (2017), Mustika et al., (2019), Firdaus, (2019), Priyanto, (2018), and Pangestika, (2018), that means the use of language in politics can be of no value because it has become a means to attack, bring down, swear, even to the scolding and spit out the ugliness of political opponents. In the aim of it by 
Brown and Levinson (in Jauhari, 2018), Thi \& Hoa, (2007, p.136) and Shang-Chao, (2008, p.67) criticism is called prone to threaten the face, because it contains a negative evaluation or a bad assessment to the person or party being criticized.

On the other hand, the use of an indirect criticizing strategy implies that criticism is aimed at improvement and suggestions by using the type of strategy asking or thinking, advice about changes, improvement, and indicating the standard. However, it is unfortunate that the use of indirect strategies is very minimal to use, although this strategy is more suitable for use in debates because in addition to criticism, speakers also provide input to a standard change and reference by expressing some more objective facts and data. That kind of criticisms which were found in the results of research conducted in developed countries, including by Pérez De Ayala, (2001), Nuolijärvi \& Tiittula, (2011), Grebelsky-Lichtman, (2016), and Jansen \& Janssen, (2010) Fracchiolla, (2011). In this case, political debates are more objective and educative because they are watched by the public at large.

\section{CONCLUSION}

Starting from data analysis and discussion, it can be concluded that the criticizing strategy chosen by TKN and BPN in the 2019 Presidential Election Debate in the "Mata Najwa" program is dominant in evaluations that are negative rather than evaluations that are constructive and improvement. This is due to criticism expressed more to things that are personal, character and ugliness of the past; rather than program and performance; which is conveyed frankly without further ado and tends to be vulgar which often ends in polemic, not only by politicians who are debating but also for their supporters in the midst of society. Because of it, the use of language in criticizing in the Presidential Election Debate was highlighted negatively because of the massive use of political interests and benefits by each party. Although political debates are more competitive in nature, the criticisms conveyed are more educative because besides the debating parties are politicians and political elites, the most important thing is that they will become leaders or public figures who will serve as role models, even references and role models for society at large. In addition, in this era of openness, where everything cannot be hidden, the debaters should prioritize substantive, objective, and educative criticism because it is watched by the public at large

\section{ACKNOWLEDGMENT}

This article is the result of the collaborative research of the Master Thesis Research Scheme 2019. Therefore, the authors express their thanks to the Chancellor of UNP and the Head of LP2M for the implementation of this research.

\section{REFERENCES}

[1] Afrizal. (2015). Metode Penelitian Kualitatif. Jakarta: PT Raja Grafindo Persada.

[2] Agustina \& Syahrul R,. (2017). Potrait of politeness in language by the supporters of governor's candidates in the discourse of Jakarta election. Journal of Scientifis Research and Studies (JSRS), Vol 4, September 2017, ISSN 2375-8791, http://www.modernspub.org/jsrs/index.htm

[3] Bargiela-chiappini. (2003). Face and politeness: new (insights) for (old) concepts. Journal of Pragmatics, 35(10-11), 1453-1469.

http://www.academia.edu/download/32433111/facepoli teness2.pdf

[4] Culpeper et al.,. (2003). Impoliteness revisited: with special reference to dynamic and prosidie aspects.

Journal of pragmatic. 35(10), 12-13.

http://www.academia.edu/download/50298010/s03782166_2802_2900118-220161114-32131-1jn24ft.pdf

[5] Fracchiolla. (2011). Politeness as a strategy of attack in a gendered political debate- the royal- sarkozy debate.Journal o pragmatic. 10(2), 5-6.

https://halshs.archives-ouvertes.fr/halshs01700024/file/Fracchiolla_25052010.pdf

[6] Firdaus (2019).Pengaruh penguasaan ragam bahasa kritik dan kalimat efektif terhadap pembelajaran menulis teks resensi.Jurnal Pendidikan Bahasa Indonesia. 1(1), 39-51.

https://journal.lppmunindra.ac.id/index.php/diskursus/ar ticle/download/3512/2412

[7] Grebelsky-Lichtman. (2016). The role of verbal and non verbal behaviour televised political debates, Journal published online. 10(15), 16-17.

https://doi.org/10.1080/15377857.2014.959688

[8] Hamdani. (2015). Kesantunan Berbahasa Pada Debat Politik, Serta Implikasinya Sebagai Bahan Ajar SMA. (Lampung: PPS Universitas Lampung).

[9] Hefdzil. (2017). Kesantunan dan ketidaksantunan berbahasa masyarakat sunda dalam dialog percakapanpada acara kunjungan keluarga di beberapa tempat di jawa.uin sunan gunung djati bandung. Jurnal al-Tsaqafa.14(1).

http://journal.uinsgd.ac.id/index.php/jat/article/downloa d/1794/1193

[10] Thi \& Hoa. (2007). "Criticizing behaviors by the vietnamese and the american: topics, sosial fators, and frequency." VNU Journal of Science. Foreign Languages:133-146 https://js.vnu.edu.vn/FS/article/view/3133/2737 
[11] Jansen \& Janssen. (2010).Efreits of positive politeness strategy in business letters.Journal of pragmatic. 36(11), 6-7.

https://www.sciencedirect.com/science/article/abs/pii/S 0378216610000627

[12] Jauhari. (2018). Alat-alat kesantunan kritik dalam masyarakat jawa surabaya: kajian pragmatic. Jurnal Mozaik Humaniora. Vol. 18 (2): 167-177 https://ejournal.unair.ac.id/MOZAIK/article/view/10931/6208

[13] Ladegaard. (2004). Politeness in young childrens speech: context peer group influence and pragmatics competence.Journal of pragmatic. 36( 11),19-20. https://www.sciencedirect.com/science/article/abs/pii/S 0378216603001772

[14] Chao.(2008). "Study on the differences of speech Act of criticism in chinese and english." US-China Foreign Language 6 (3).

[15] Mustika, T.P, Agustina, dan Syahrul R. (2019). Verbal violence performed by supporters group of gubernatorial candidates in the political discourse of Jakarta election. HUMANUS, Volume 18 No. 01. 2019, page 88-100. ISSN 1410-8062 (printed) dan ISSN 2928-3936 (online), available at http://ejournal.unp.ac.id/index.php/humanus/index

[16] Nuolijärvi \& Tiittula. (2011). Irony in political television debates, Journal of pragmatic. 43(2), 35-36. https://www.sciencedirect.com/science/article/abs/pii/S 0378216610000329

[17] Nguyen. (2005)" Critizing in An 12: pragmatic strategies used by vietbames efl. Learners intercultural Pragmatics. 5(1), 41-46.

[18] Nguyen. 2008. "Criticizing in an L2: Pragmatic Strategies Used by Vietnamese EFL Learners.” http// www. reference-global.com/doi/pdf plus/10.1515/IP.2008.003.

[19] Panca. (2016). Analisis ketidaksantunan dalam perang kicauan antar kubu calon presiden amerika serikat pada pilpres 2016.Etnolingual. 1(1), 169-188.

[20] Pangestika, Agustina, dan Ngusman A.M. (2018). Kesantunan berbahasa para politikus dalam wacana politik DKI Jakarta 2017 di portal berita online. Thesis.Universitas Negeri Padang.

[21] Pérez De Ayala, (2001). Conflicting needsa?politenes in questation time, Journal pragmatic, 35(10), 9-10.

[22] Priyanto. (2018).Analisis kesantunan berbahasa dalam debat publik calon bupati kabupaten kerinci tahun 2018. Jurnal Pena.7(2).
[23] Rudanko. (2006). Aggraved impoliteness and two types of speaker intention in an episode in shakespear as timon of athens. Journal of pragmatic. 38(6), $20-24$.

[24] Rusminto. (2012). Analisis Wacana Sebuah Kajian Teoritis dan Praktis. Bandarlampung: Universitas Lampung.

[25] Walker et al., (2012). That is your evidence: Classifying stance in online political debate, Journal pragmatic. 10(13), 12-16.

[26] Wibowo. (2013). Semiotika Komunikasi. Aplikasi Praktis Bagi Penelitian dan Skripsi Komunikasi. Jakarta: Mitra Wacana Media.

[27] Widyamartaya. (1991). Menulis Narasi dan Deskripsi. Jakarta: Gramedia Pustaka Utama

[28] Yusri. (2015). Pelanggaran kesopanan berbahasa dalam komunikasi politik pada pemilihan gubernur Sulawesi Selatan 2013. Jurnal Parole. 5(1),15-16.

https://ejournal.undip.ac.id/index.php/parole/articl e/view/8576 